\title{
FAIR REPRESENTATION AND BREACH OF CONTRACT IN SECTION 301 EMPLOYEE-UNION SUITS: WHO'S WATCHING THE BACK DOOR?
}

Section 301 of the Labor Management Relations $\mathrm{Act}^{1}$ has provided both unions ${ }^{2}$ and employers ${ }^{3}$ with a federal forum ${ }^{4}$ for suits to enforce collective bargaining agreements. Initial furor as to whether the section merely provided federal jurisdiction for the application of state law, or instead was enacted to allow federal judges to apply federal common law, has gradually subsided, as the latter view has gained prevalence. ${ }^{5}$

In recent years it has also become settled that section 301 empowers an employee to bring suit against his employer for breach of contractually-created employee rights. ${ }^{6}$ The courts have not, however, definitively resolved the question which is the subject of this Comment: whether section 301(a) also provides jurisdiction for an employee suit against a union for breach of contract. Of course, such a suit can arise under the section only in those comparatively rare situations in which a union breaches a covenant it made with an employer, by which it conferred third-party beneficiary rights upon employees. Such provisions arise relatively infrequently for the obvious reason that the norm in collective bargaining is for management to extract promises redounding directly to its own benefit, rather than to bargain altruistically on behalf of its employees. Within the fairly narrow

'Section 301(a) provides:

Suits for violation of contracts between an employer and a labor organization representing employees in an industry affecting commerce ... or between any such labor organizations, may be brought in any district court of the United States having jurisdiction of the parties ....

29 U.S.C. $\S 185$ (a) (1970).

${ }^{2}$ See, e.g., Retail Clerks Local 1222 v. Alfred M. Lewis, Inc., 327 F.2d 442 (9th Cir. 1964); United Steelworkers v. Copperweld Steel Co., 230 F. Supp. 383 (W.D. Pa. 1964).

${ }^{3}$ See, e.g., Electrical Contractors Ass'n v. Local 103, IEW, 458 F.2d 590 (1st Cir. 1972); Shirley-Herman Co. v. Hod Carriers Local 210, 182 F.2d 806 (2d Cir. 1950).

${ }^{4}$ State courts do retain concurrent jurisdiction to adjudicate $\S 301$ claims. Amalgamated Ass'n of St. Employees v. Lockridge, 403 U.S. 274, 298 (1970); Charles Dowd Box Co. v. Courtney, 368 U.S. 502, 513 (1962).

Absent $\S 301$ jurisdiction, collective bargaining enforcement would be relegated to state forums, where its efficacy would depend entirely upon the adequacy of state remedies. See Textile Workers Union v. Lincoln Mills, 353 U.S. 448 (1957).

${ }^{5}$ See Textile Workers Union v. Lincoln Mills, 353 U.S. 448 (1957).

${ }^{6}$ Smith v. Evening News Ass'n, 371 U.S. 195 (1962).

If the collective bargaining agreement provides for compulsory and binding grievance procedures, an employee must of course first exhaust those contractual remedies. An employee who has done so unsuccessfully will be denied judicial review of his claim unless he can demonstrate that his union failed to fairly represent his interests. See, e.g., Vaca v. Sipes, 386 U.S. 171, 186 (1967). If the employee can prove that the union breached its duty of fair representation, see text accompanying notes 60-67 infra, he may obtain relief against both it and his employer. See, e.g., 386 U.S. at 187-88. 
class of cases in which a union makes third-party promises to its employees, however, the employee need for a federal forum is no less compelling than in any breach of contract case between union and management. ${ }^{7}$

A case which recently confronted the Ninth Circuit, Buzzard v. Machinists Local 1040, ${ }^{8}$ illustrates employee desire for access to federal court in a breach of contract suit against his union. In Buzzard, several employees ignored the instructions of their union officials and crossed the picket lines of a second union involved in a strike against a common employer. Subsequently, upon the termination of that labor dispute, a written strike settlement agreement ${ }^{9}$ between the first union and the employer provided that neither would initiate proceedings for damages or other relief in any forum for any cause arising out of the labor dispute. ${ }^{10}$ The union reneged on its promise and instituted internal disciplinary proceedings against its employees for their refusal to honor the picket line.

When the employees instituted suit in federal court to enjoin the pending disciplinary proceedings, the Ninth Circuit noted their failure to exhaust intraunion remedies and dismissed the case. In expansive dictum, however, it suggested that federal courts have jurisdiction in such suits under section $301 .{ }^{11}$ The court reasoned simplistically: it began with the proposition that section 301 empowers federal courts to entertain suits for violations of contracts between an employer and a union. ${ }^{12}$ The court then concluded that section 301(a) supported an employee suit for redress of union interference with employee collective bargaining rights when such interference constituted a breach of the

7 Provision of a federal forum for the enforcement of private labor contracts was motivated in part by fear of antiunion sentiment in state courts, and by concern at the inadequacy of state remedies. See Textile Workers Union v. Lincoln Mills, 353 U.S. 448 (1957). Even if state antiunionism might be less prejudicial where the union's adversary is an employee, not an employer-a dubious assumption-the absence of a federal forum could still preclude employees from obtaining remedies appropriate to their injuries. It would mean also that the accumulated experience of federal courts in employer-union contract suits would be lost to all parties. $C f$. id.

${ }^{8} 480$ F.2d 35 (9th Cir. 1973).

${ }^{9}$ In Retail Clerks Local 128 v. Lion Dry Goods, Inc., 369 U.S. 17, 25-28 (1962), the Court rejected the notion that the term "contract" as used in $\$ 301(\mathrm{a})$ denoted only full collective bargaining agreements establishing wages, hours and other terms and conditions of employment. Instead, it found any agreement "significant to the maintenance of labor peace between" employers and labor organizations-including strike settlement agreements between an employee and a minority union-to be a "contract" within the meaning of $\S 301(a)$.

10 The agreement stated:

Northwest Airlines and the IAM, their members and their officers, will not initiate any further actions or proceedings in any court or before any agency or in any other forum seeking damages or any other relief for any claim or cause arising out of the circumstances of the strike ....

480 F. $2 \mathrm{~d}$ at 38 .

${ }^{11} I d$. at 40 .

${ }^{12} \mathrm{Id}$. 
union's duty of fair representation. ${ }^{13}$ Suggesting that the question whether an employee could sue his union for breach of contract under section 301 (a) was one of first impression, ${ }^{14}$ the Ninth Circuit concluded that precedent supported the inference that the section provided federal jurisdiction for an employee suit against a union when the union arbitrarily and in bad faith refused to honor promises made in collective bargaining agreements, since such refusal would constitute a breach of the duty of fair representation.

The Ninth Circuit's Buzzard decision appears to have been arrived at by an erroneous reading of jurisdictional case law and a faulty analysis of the duty of fair representation. These two separate errors by a court of some distinction illustrate the elusiveness of these basic jurisdictional and representational issues, and provide convenient points of departure for an analysis of both section 301 and the duty of fair representation.

\section{Section 301 and the Federal Courts}

The first error of the Buzzard court-its conclusion that section 301 by itself conferred jurisdiction over fair representation suits-may have been partly academic, ${ }^{15}$ but nonetheless illustrated dangerously imprecise judicial reasoning. ${ }^{16}$ For if a fair representation action were appropriate in the Buzzard context, ${ }^{17}$ such an action would necessarily have arisen under the federal labor statutes, not under section 301. Section 301, properly analyzed, appears to support jurisdiction only for breach of contract suits.

\section{A. Fair Representation Jurisdiction Under Section 301}

The duty of fair representation arises by implication from the exclusive representation provisions of federal labor statutes. ${ }^{18}$ Accordingly, the Supreme Court noted in Vaca $v$. Sipes $^{19}$ that when employer and union are bound by a collective bargaining agreement, it was "well established" that a union had not a contractual but "a statutory duty fairly to represent all of

${ }^{13}$ The court cited Humphrey v. Moore, 375 U.S. 335, 343-44 (1964) for this proposition. But see notes 33-41 infra \& accompanying text.

${ }^{14}$ But see notes $42-48$ infra \& accompanying text.

15 That is, if a fair representation suit were the proper vehicle for employee redress, federal jurisdiction could be found before the federal courts albeit not under $\$ 301$.

${ }_{16}$ The court could easily have adopted the theory that an arbitrary refusal to honor contractual promises was a hybrid fair representation-breach of contract wrong which could give rise to jurisdiction under either the representation statutes or $\S 301$. The court did not so reason, however, but instead assumed that any fair representation suit involving a collective bargaining agreement could be brought under § 301 .

${ }^{17}$ But see notes 49-92 infra \& accompanying text.

${ }^{18}$ See notes 62-67 infra \& accompanying text.

19386 U.S. 171 (1967). 
[its] ... employees in its enforcement of the ... collective bargaining agreement ... [and] that [plaintiff's fair representation] complaint alleged a breach by the Union of a duty grounded in federal statutes . . .."20 Thus, authority to sue for breach of the duty of representation ordinarily flows from those statutes, which predate the jurisdictional provisions relating to enforcement of collective bargaining agreements. ${ }^{21}$

Section 301 has provided jurisdiction for fair representation suits, however, when such suits have been annexed to section 301 breach of contract suits against employers, since, in the latter, proof of defective union representation is a prerequisite to obtaining relief against the employer. ${ }^{22}$ Loose judicial dictum may have created some confusion as to this matter ${ }^{23}$ and intimated that-since fair representation suits routinely involve collective bargaining contracts-section 301 jurisdiction could be obtained even without allegations of breach of contract. None of the three cases cited by the Buzzard court, however, supports that jurisdictional view. Humphrey $v$. Moore ${ }^{24}$ for example, involved allegations of breach of contract against both employer and union, and a claim that the union had breached its duty of fair representation. Ford Motor Co. v. Huffman ${ }^{25}$ involved a claim that

\footnotetext{
${ }^{20} \mathrm{Id}$. at 177 (emphasis added).

${ }^{21}$ Considerable debate has centered on whether a violation of the duty of fair representation also constitutes an unfair labor practice properly dealt with by the Board itself, rather than by state or federal courts. Compare Local 12, United Rubber Workers v. NLRB, 368 F.2d 12 (5th Cir. 1966) (union's racially discriminatory practices violated § 8(b)(1)(A)), with NLRB v. Miranda Fuel Co., 326 F.2d 172 (2d Cir. 1963) (arbitrary union action did not violate $\S \S 8(b)(1)-(2))$.

Whatever the ultimate outcome of that controversy, the Court has clearly rejected the view that adoption of that theory would trigger the pre-emption doctrine enunciated in San Diego Building Trades Council v. Garmon, 359 U.S. 236 (1959), and thus give the Board exclusive jurisdiction over all duty of fair representation questions except those linked to a $\$ 301$ breach of contract claim. Vaca v. Sipes, 386 U.S. 171, 176-88 (1967). Thus, federal courts appear likely to retain jurisdiction over duty of fair representation questions.

Currently, duty of fair representation questions will be heard before the Board only under limited circumstances. The Board may, for example, act to decertify unions who refuse to discharge that duty. 29 U.S.C. $\$ 159$ (c)(1)(A)(ii) (1970); see, e.g. A.O. Smith Corp., 119 N.L.R.B. 621 (1957).

${ }_{22}$ See note 6 supra. See also Pelofsky \& Pelofsky, Emplojee's Rights Under The National Labor Relations Act, 32 Mo. L. REv. 211, 227-28 (1967).

Thus, because the necessary nexus with a companion suit against the employer was lacking, Buzzard could clearly have not been brought as a fair representation action under $\S 301$.

${ }_{23}$ In Amalgamated Ass'n of St. Employees v. Lockridge, 403 U.S. 274 (1970), for example, the Court declared that $\$ 301$ would support

a suit in the state courts by a union member against his union that seeks to redress union interference with rights conferred on individual employees by the employer's promises in the collective-bargaining agreement, where it is proved that such interference constituted a breach of the duty of fair representation.

Id. at 299 (emphasis added), citing Humphrey v. Moore, 375 U.S. 335, 350 (1963). Yet in Humphrey it was made clear by the Court that the union interference did not constitute such a breach. 375 U.S. at 351 .

24375 U.S. 335 (1963). See text accompanying notes 33-41 infra.

25345 U.S. 335 (1952).
} 
an employer's grant of special seniority to workers with preemployment military service violated employee rights and an allegation that the union's acquiescence in that provision breached its duty of fair representation. Finally, Falsetti $v$. Local 2026, UMW, ${ }^{26}$ was a routine action against both employer and union for alleged breach of contractual seniority provisions in which the union was also charged with having breached its duty of fair representation.

\section{B. Employee Breach of Contract Suits}

Although section 301 does not provide jurisdiction for fair representation suits, it apparently does furnish jurisdiction for employee breach of contract suits against unions. On its face, ${ }^{27}$ the statute does not specify who may sue to enforce contractual provisions between unions and employers. In Smith v. Evening News Association, ${ }^{28}$ however, the Supreme Court held that section 301 used the word "between" to refer to contracts between employers and unions, not to suits between them, and thus that section 301 permitted employees to sue to "vindicate individual employee rights arising from a collective bargaining contract . ..."29 Although Smith dealt only with employee-employer suits, its simple logic seems to compel the conclusion that individual employees ought to be permitted to sue their unions in vindication of the same rights.

Unfortunately, the legislative history of section 301(a) is inconclusive on this point, ${ }^{30}$ and fails to reveal whether Congress contemplated that employees would have resort to the federal courts in such suits. Proponents of section 301 were primarily concerned with affording employers a federal remedy for union misconduct, ${ }^{31}$ while its opponents railed against the antiunion sentiment evidenced by establishment of this employer remedy. ${ }^{32}$ With attention focused on the merits of employer-union suits, the issue of employee access to the federal courts received scant consideration.

${ }^{26} 355$ F.2d 658 (3d Cir. 1966).

${ }^{27}$ See note 1 supra.

${ }^{28} 371$ U.S. 195 (1962).

${ }^{29} \mathrm{Id}$. at 200.

${ }^{30} \mathrm{~A}$ search of the Congressional Record reveals only one comment of even arguable relevance, in which Congressman Barden indicated his understanding that $\$ 301$ contemplated not only damage suits, but also the possibility that interested employees might bring suit under the Declaratory Judgment Act to secure declarations of contractual rights. 93 CoNG. Rec. 3656 (1947).

The legislative history of $\$ 301$ is well compiled in Textile Workers Union v. Lincoln Mills, 353 U.S. 448, 485-546 (1957) (Frankfurter, J., dissenting) (appendix).

${ }^{31} \mathrm{See} 93$ Cong. REC. 4207 (1947) (remarks of Senator Morse).

${ }^{32}$ See 92 CoNG. REC. 5412-15 (1946) (remarks of Senator Magnuson). 


\section{Humphrey v. Moore}

One ambiguous decision of the Supreme Court may, however, have already recognized-albeit tacitly-the right of an employee to sue his union under section 301 for breach of a labor contract. In Humphrey $v$. Moore, ${ }^{33}$ a single collective bargaining agreement binding several employers and several local unions provided, inter alia, that in the event one employer absorbed the business of another the seniority of the absorbed or affected employees would be determined by mutual agreement between the employer and the affected union. ${ }^{34}$ It stipulated, in addition, that grievances were to be processed initially by the employer and the local. If unresolved at that level, they would be submitted to a local joint committee, and if no settlement were agreed upon there the grievances were to be further forwarded to a "Joint Conference Committee," whose decisions would be final and binding on all parties.

The contractual dispute in Humphrey arose when two employers, E \& L Transport Company (E \& L) and Dealers Transport Compay (Dealers) were notified by Ford Motor Company that a decrease in auto sales meant that one of them could no longer be employed to transport Ford cars from Louisville to points south. E \& $\mathrm{L}$ agreed to abandon its franchise, in return for a reciprocal concession by Dealers at a northern plant.

Facing imminent layoff, $\mathrm{E} \& \mathrm{~L}$ employees filed grievances pursuant to the seniority-merger provision of their collective bargaining agreement. They demanded that their seniority be "dovetailed" or "sandwiched" with that of Dealers' employees, so that employees from either company with the least seniority would be the first to be discharged. The Joint Conference Committee agreed that sandwiching was the most equitable solution to the seniority issue, ${ }^{35}$ and thereby triggered a suit by Dealers employees who sought to enjoin implementation of the Committee's decision.

In their complaint, the Humphrey plaintiffs alleged discharge without just cause on two grounds. First, they alleged, there had been no "absorption" of an employer within the contractual meaning of that term, and thus the Joint Conference Committee had exceeded its authority under the collective bargaining agreement by resolving the seniority question. Thus, they reasoned, the Committee's resolution was void, plaintiffs were entitled to retain their original seniority, and their discharge was without good cause. ${ }^{36}$ Second, plaintiffs alleged that the

33375 U.S. 335 (1964).

${ }^{34} I d$. at 338 .

${ }^{35} I d$. at 339 .

${ }^{36} I d$. at 342 . 
Committee's agreement was void because the union had breached its duty of fair representation. Accordingly, they reasoned, their original seniority remained intact and their discharge was again without cause. ${ }^{37}$

On the basis of the complaint, the Court ruled Humphrey arose "under $\S 301$ of the Labor Management Relations Act and [was] . . . controlled by federal law ...."38 On the merits, the Court concluded that "[n]either the parties nor the Joint Committee exceeded their power under the contract and there was no fraud or breach of duty by the exclusive bargaining agent." 39 Never clearly explicated, however, was why the Court has jurisdiction over each defendant.

The Humphrey Court may have bottomed its finding of section 301 jurisdiction on either of two grounds. First, it may have held only that the plaintiffs' first allegation established a section 301(a) cause of action against the employer for breach of contract-wrongful discharge-and that their second allegation supported an annexed suit against the union for dereliction of its representation duty. ${ }^{40}$ It is equally reasonable, however, to theorize that the Court found the plaintiffs' first allegation to have established breach of contract jurisdiction over both employer and union, the union's breach having occurred when union representatives on the Joint Committee exceeded their power and decided an issue outside their proper jurisdiction. ${ }^{41}$ At no point did the Court intimate that an employee-union breach of contract suit was improper.

\section{Lower Court Unanimity}

The Supreme Court's recognition of section 301 jurisdiction for employee-union breach of contract suits in Humphrey was at

${ }^{37} I d$.

${ }^{38} I d$. at $343-44$ (footnote omitted).

${ }^{39} \mathrm{Id}$. at 351 .

${ }^{40}$ See text accompanying note 22 supra.

${ }^{41}$ Comment, Refiusal To Process $A$ Grievance, The NLRB And The Duty Of Fair Representation: A Plea for Preemption, 26 U. PIrT. L. Rev. 593, 610 (1965) [hereinafter cited as Refusal To Process A Grievance].

The union could arguably have breached a promise implicit in agreed-upon grievance procedures that the union would fairly represent all bargaining unit workers. See Ferguson, Duty Of Fair Representation, 15 LAB. L.J. 596 (1964); Comment, Union's Duty To Fairly Represent Its Members in Contract Grievance Procedures-The Impact of Vaca v. Sipes, 19 Syracuse L. Rev. 66, 72 (1967); Refusal To Process A Grievance, supra, at 611 .

Such a theory, however, falters under analysis. A study of the case law reveals no recognition of it. The duty of fair representation is statutorily imposed, see notes 62-67 infra \& accompanying text, and § 301 (a) supports fair representation actions only when properly appended to a breach of contract suit against the employer, see Vaca v. Sipes, 386 U.S. 171, at 186-87.

For a discussion of the only Supreme Court case referring to the Humphrey holding, see note 23 supra. 
best implicit. The federal courts that have considered the question have also unanimously recognized this jurisdictional right.

In Bryant $v$. Intermational Union, UMW, ${ }^{42}$ for example, the relevant collective bargaining agreement gave the union a right to demand that the company comply with specified safety regulations. Disgruntled employees alleged that the provision obligated the union to enforce compliance, and sued the union for breach of the labor contract as well as for breach of its duty of fair representation. While deciding on the merits against the employees, the Sixth Circuit implicitly acknowledged their right to sue the union under section 301(a) for breach of contract. ${ }^{43}$

Similarly, in Bieski v. Easterm Automobile Forwarding Company, ${ }^{44}$ a collective bargaining agreement had empowered a Joint Conference Committee of management and union representatives to resolve seniority problems arising from employer mergers. Nonetheless, the Committee refused to entertain employee requests for the dovetailing of seniority subsequent to the failure of one of the employers. The plaintiffs alleged that the union breached its duty of fair representation, and that both union and management breached the collective bargaining agreement, in refusing to entertain the grievance in Committee. The Third Circuit intimated that section 301(a) conferred jurisdiction for breach of contract suits against their union by employees simply because the seniority rights in controversy. arose from a collective bargaining contract, and held the Committee obligated to entertain the seniority question.

Finally, ${ }^{45}$ in Bey $v$. Muldoon, ${ }^{46}$ employees sued to enforce collective bargaining agreement provisions which established a fund, to be administered jointly by the union and the employer, for the benefit of sugar workers who had lost employment opportunities as a result of technological innovations in the industry. The employees alleged that both union and management had breached the labor contract by making disbursements from the fund to workers not involved in sugar production. Denying a motion to dismiss, a Pennsylvania district court declared that section 301(a) jurisdiction lay for an employee breach of contract suit against the union, explaining that if an employer

42467 F.2d 1 (6th Cir. 1972), cert. denied, 41 U.S.L.W. 3448 (U.S., Feb. 20, 1973).

${ }^{43}$ See $i d$. at 3 . The court assumed without deciding that the employee had standing to sue for breach of contract, id. at 2 n.l. It must be borne in mind that the issue of standing is preliminary to and wholly distinct from the question whether employee breach of contract suits fall within $\S 301$ 's jurisdictional provisions.

14396 F.2d 32 (3d Cir. 1968).

45 Other cases supporting $\$ 301$ jurisdiction for employee-union breach of contract suits include Abruscato v. Industrial Workers Local 199, $58 \mathrm{CCH}$ Lab. Cas. ๆ 12,955 at 22,547 (S.D.N.Y. 1968), and Lee v. Olin Mathieson Chem. Corp., 271 F. Supp. 635, 638 (W.D. Va. 1967).

${ }^{16} 217$ F. Supp. 404 (E.D. Pa. 1963), cert. denied, 384 U.S. 987 (1966). 
is subject to suit "the union, a party to the contract . . . [is a] logical ... [party] to a suit which will of necessity interpret that contract." 77 Significantly, the court suggested that Smith v. Evening News Association ${ }^{48}$ disposed of the contention that section 301 gave an employee no authority to sue his union. Thus, the Bey court's recognition of jurisdiction cannot fairly be limited to suits in which, as in Bey, an employer is a codefendant.

\section{Fair Representation and Federal Labor Policy}

It seems clear that other statutes than section 301 must be invoked to provide jurisdiction for a fair representation suit. It seems clear also that section 301 will, on the other hand, suffice to provide jurisdiction for a breach of contract action. The question remaining, then, is which type of action is appropriate on the basis of the Buzzard allegations.

In Jost v. Machinists, Grand Lodge ${ }^{49}$ plaintiff, an employee, alleged breach by his union of a contractual provision which prohibited it from coercing employees into becoming union members. He was held to have stated only a claim for breach of the duty of fair representation, and not a breach of contract claim cognizable under section 301. Likewise, in Richardson $v$. Communications Workers, ${ }^{\mathbf{5 0}}$ the relevant collective bargaining agreement contained covenants by both employer and union not to discriminate against any employee on the basis of union affiliation. The Richardson plaintiff, after withdrawing from union membership, was subjected to continuing harassment by union members at his jobsite. After a fight with one of his tormentors, he was discharged by the employer. Thereafter, he filed a section 301(a) action against both employer and union for breach of the antidiscrimination clause. The Eighth Circuit noted that the plaintiff's claim against the union "misconstrue[d]" the relationship between the parties to a collective bargaining agreement. The union, it reasoned, was "signatory to the agreement on behalf of all the employees," and served "in the capacity of a fiduciary to the employees." Thus, it declared, breach of that agreement by the union

created a claim for breach of trust of its statutory duty to give adequate representation ... [not] one arising out of the collective bargaining contract. ... [W] hen the employee seeks individual relief arising from union discrimination he need only look to the statutory duty of the union to adequately represent him. ${ }^{51}$

${ }^{47}$ Id. at 406 .

${ }^{48}$ See text accompanying notes 28-33 supra.

$4969 \mathrm{CCH}$ Lab. Cas. ๆ 12,988 , at 25,152 (D. Neb. 1972).

30443 F.2d 974 (8th Cir. 1971).

${ }^{51}$ Id. at $980-81$ (footnote omitted). 
It was in this vein that the Buzzard court assumed that a union failure to abide by its contractual promises, if tantamount to "fraud, deceitful action, or dishonest',"52 would constitute a traditional breach of the duty of fair representation.

The Richardson assertion that an employee seeking relief for injury resulting from union contractual misconduct "need only look to the statutory duty of the union to adequately represent him" ignores serious policy problems which underlie the superficially benign Buzzard view. In fact, the duty of fair representation should not be invoked unless it can be shown that union conduct impaired or allowed the impairment of employee $j o b$ interests. The contrary Buzzard assumption represents an expansion of the duty of fair representation which may have been not only doctrinally unsupportable ${ }^{53}$ but unwise. While the duty ought not be construed stingily, ${ }^{54}$ the Buzzard court's construction of it could, by importing the law of fair representation into the breach of contract area, imperil the very goals the duty was designed to further.

\section{A. The Duty of Fair Representation}

As evidenced by sections 8(a)(1)-(5) of the National Labor Relations Act, ${ }^{55}$ one major goal of national labor policy has long been to maximize the rights of individual workers. ${ }^{56}$ Prominent among the rights to be fostered and protected is the right of employees to band together to organize and concentrate their economic strength. ${ }^{57}$ Unions arose in an effort to combine the minimal economic power of individual employees in a single

The Richardson court's authority is undermined by its casual assertion, $i d$. at 980 n.6, that Vaca v. Sipes, 386 U.S. 171 (1967) - in which the plaintiff employee had asserted no contractual claim against his union-afforded support for this position. In Vaca, plaintiff was discharged by his employer because of a heart condition. After the union retused to pursue the employee's claim of wrongful discharge to final arbitration, he filed suit for breach of the duty of fair representation 386 U.S. at 174-76. No union breach of contract, however, was even arguable in the Vaca context.

52480 F.2d at 40, quoting Humphrey v. Moore, 375 U.S. 335, 348 (1964); Amalgamated Ass'n of St. Employees v. Lockridge, 403 U.S. 274, 299 (1971).

53 Past Supreme Court decisions have clearly made reference to fraud as the standard by which union representation is to be measured. Humphrey v. Moore, 375 U.S. 335, 348 (1964), for example, suggested that "substantial evidence of fraud, deceitful action, or dishonest conduct" was required before breach of the fair representation duty could be found; Amalgamated Ass'n of St. Employees v. Lockridge, 403 U.S. 274,299 (1971) voiced identical criteria. See also text accompanying notes 81-85 infra. Neither case, however, dealt in the slightest with the question whether a union's breach of contract must be "fraudulent" to give rise to relief, or whether in such cases the duty of fair representation would be the sole source of employee relief.

${ }_{54}^{4}$ See Clark, The Duty of Fair Representation: $A$ Theoretical Structure, 51 TEXAs L. REv. $1119,1177-78$ (1973). Ms. Clark suggests that increased union strength vis-a-vis both management and employees has made expansion of the duty "mandatory," and that "[t]he added protection that workers would gain from expanding the duty of fair representation to forbid irrational action would outweigh the disadvantages to their unions."

${ }_{55} 29$ U.S.C. $\S \S 158(a)(1)-(5)(1970)$.

${ }^{36}$ See id. \$ 157; cf. McClintock, Enterprise Labor And The Developing Law Of Employee Job Rights: Part One, 8 Gonzaga L. Rev. 40, 50 (1972).

${ }_{37}$ See 29 U.S.C. \& $158(a)(1),(3)(1970)$. 
entity, capable of counterbalancing the economic bargaining might of employers. Perhaps the foremost function of the union from the very outset was the protection of individual employees from employer caprice.

It is inevitable, of course, that over time unions-like all organizations-may develop interests that diverge from the individual interests of their members. ${ }^{58}$ Such divergence frequently arises in the administration of a collective bargaining agreement, where the desire of union and employer to accommodate each other's interests for the sake of harmony-dubbed by some the "spirit of accommodation"-may spell "difficulty for individual rights of the employees."59

Thus it was that the duty of fair representation was given birth. That duty arose to remedy invidious or hostile union treatment of its members, ${ }^{60}$ and thus to compel the union to protect employee job interests against impairment by the employer. The Supreme Court noted in Vaca v. Sipes ${ }^{61}$ that, as the exclusive bargaining representative of employees, a union has a duty "fairly to represent all of those employees, both in its collective bargaining ... and in its enforcement of the resulting collective bargaining agreement ...."

The Supreme Court first enunciated the doctrine of fair representation in Steele v. Louisville $\mathcal{E}$ Nashville R.R., ${ }^{62}$ a suit by black railroad employees against their union to enjoin implementation of a union-negotiated agreement, the provisions of which restricted hiring and tenure opportunities for blacks as locomotive firemen. The Court noted that section 2(4) of the Railway Labor Act ${ }^{63}$ explicitly empowered a union elected by a majority of the employees in a collective bargaining unit to represent exclusively all unit members in collective bargaining. That provision, however, was found to impose on the union the duty to represent the interests of all unit members equally. ${ }^{64}$ The hostility displayed by the union toward black employees clearly

${ }^{58}$ See, e.g., Comment, Federal Protection Of Individual Rights Under Labor Contracts, 73 YALE L.J. 1215 (1964).

59 Blumrosen, The Worker And Three Phases Of Unionism: Administrative And Judicial Control Of The Worker-Union Relationship, 61 MrcH. L. REv. 1435, 1436, 1465 (1963).

A union may, for example, choose not to press the valid grievance of an employee irksome to management, in return for reciprocal consideration from the employer when a union shop steward runs afoul of work rules. The "spirit of accommodation," by encouraging an employer to forgo or soften disciplinary measures against the steward, may coincide with the interests of both employer and union. This coincidence, however, is at the expense of the employee with a meritorious grievance, who is left adrift by the union. (1971).

${ }^{60}$ See, e.g., Amalgamated Ass'n of St. Employees v. Lockridge, 403 U.S. 274, 301

${ }_{61} 386$ U.S. at 177.

62323 U.S. 192 (1944).

${ }^{63} 45$ U.S.C. \& 152(4) (1970).

64323 U.S. at 202. 
breached this statutorily-implied duty. In a similar case involving union discrimination against blacks in the negotiation of a collective bargaining agreement, the Court reversed a Fifth Circuit decision $^{65}$ and held that section 9(a) of the National Labor Relations Act ${ }^{66}$ designating a union elected by a bargaining unit majority as the exclusive agent for that unit, impliedly established a union duty of fair representation. ${ }^{67}$

The courts have expanded the perimeters of the duty of fair representation to preclude not only hostile discrimination against racial minorities, but also bad-faith discrimination against any defined employee group during the negotiation and administration of a collective bargaining agreement. ${ }^{68}$ Thus, if a group of employees can prove that a union refused in bad faith to negotiate with management to eliminate differential wage scales for employees performing essentially similar work, they have established a breach of the duty of fair representation. ${ }^{69}$ Similarly, if an employer abandons one installation for another with a consequent reduction in the number of available jobs, a union would breach its duty by approving the employer's use of political considerations in choosing one particular group of employees for the remaining positions. ${ }^{70}$ Furthermore, a union may not for hostile reasons ${ }^{71}$ undertake discriminatory action against an individual employee. For example, if it refuses a member's timely tender of dues and thereafter expels him from membership because those dues were in arrears, with the result that management dismisses the member under union shop provisions in the collective bargaining agreement, ${ }^{72}$ the duty has been breached.

\section{B. Limitations on the Duty of Fair Representation}

While the duty of fair representation affords important protection for worker interests, it must be noted that its protection is neither all-embracing nor all-powerful. It is not allembracing because the duty does not ordinarily extend to union conduct unrelated to the negotiation or administration of a collective bargaining agreement. It is hardly all-powerful, even within its proper domain, because it accords a union extraordi-

6s Syres v. Oil Workers Local 23, 223 F.2d 739, 743 (5th Cir. 1955).

6629 U.S.C. $\S 159$ (a) (1970).

${ }^{67}$ Syres v. Oil Workers Local 23, 350 U.S. 892 (1955) (per curiam).

${ }^{68}$ See, e.g., Ford Motor Co. v. Huffman, 345 U.S. 330, 337 (1953); Gainey v. Brotherhood of Ry. \& S.S. Clerks, 313 F.2d 318, 322-23 (3d Cir. 1963). 1963).

${ }^{69}$ See, e.g., Gainey v. Brotherhood of Ry. \& S.S. Clerks, 313 F.2d 318, 323 (3d Cir.

${ }_{70}^{70}$ See, e.g., Ferro v. Railway Express Agency, Inc., 296 F.2d 847, 851 (2d Cir. 1961).

${ }^{71}$ Cunningham v. Erie R.R., 266 F.2d 411 (2d Cir. 1959).

72 Brady v. Trans World Airlines, Inc., 174 F. Supp. 360, 363 (D. Del. 1959). For a full exploration of the contemporary contours of the duty of fair representation, see Clark, supra note 54. 
narily broad discretion in the discharge of its representation function.

\section{Employee-Employer Relations}

It must be noted that however arbitrarily the Buzzard union acted in reneging upon its promise not to discipline its members, its threatened disciplinary action in no way bore upon the negotiation and administration of the collective bargaining agreement. The union's breached promise did not relate to its primary function of representing employee interests against management, but instead involved a purely internal employeeunion matter. It would therefore be preferable to conclude that the duty of fair representation was not properly involved in Buzzard.

Exclusion of all intraunion conduct from the duty of fair representation would defeat the protective aims of that duty, for "internal union policies and practices may have a substantial impact upon the external relationships of members of the unit to their employer."73 Wrongful union expulsion of a member for purely "internal" matters, for example, could represent a breach of the duty of fair representation because it could compel or simply allow an employer to discharge that member under union shop provisions.

Nonetheless, a requirement that union misconduct bear directly 'upon the employer-employee relation to constitute a breach of the duty of fair representation has been felt necessary. The fear has been expressed that otherwise a union would be "exposed to harassing litigation by dissident members over every arguable decision made in the course of the day-to-day functioning of the union." Thus, though the duty of fair representation is broad, it does not include union practices without a "substantial impact upon members' rights in relation to the negotiation and administration of the collective bargaining agreement."74 Wholly apart from the fear of harassing litigation in minor matters, however, considerations of worker protection and economic stability militate against resort to the duty of fair representation to support a Buzzard-type claim.

Application of the fair representation standard ordinarily

${ }^{73}$ Retana v. Apartment \& El. Op. Local 14, 453 F.2d 1018, 1024 (9th Cir. 1972).

${ }^{74} \mathrm{Id}$. at 1024-25. See also text accompanying note 59 supra. In Retana, a Spanishspeaking employee-allegedly discharged without good cause-sued her union for breach of the duty of fair representation. The plaintiff claimed that her union had failed to provide her with a translated copy of the labor agreement, supply her with a bilingual liaison to the union hierarchy, or simply to explain her rights under the contract. The court held that the plaintiff should be entitled to prove her allegations, since proof that a minority group was denied enjoyment of collective bargaining rights by its union's exploitation of a language barrier would represent a breach of the fair representation duty. $453 \mathrm{~F} .2 \mathrm{~d}$ at 1024 . Such exploitation would, it should be noted, have permitted the employer to encroach at will upon her job interests. 
results in the subordination of individual employee interests to union organizational needs. ${ }^{75}$ This is troubling ${ }^{76}$ but ultimately tolerable under a scheme of exclusive representation, so long as a union is administering a collective bargaining agreement and specific union promises to its members are not at stake. Unions should ordinarily be entitled to considerable discretion under such circumstances, as they should have no overriding interest apart from the "spirit of accommodation" in aiding an employer. A union's very ability to represent its members effectively would only be imperiled by closer judicial scrutiny of asserted employee rights.

Subordination of employee rights to union organizational interests becomes unsatisfactory, however, where union breaches of specific contractual promises bearing solely upon the employee-union relation are at issue. If a union's breach of such promises is subjected only to the ordinary fair representation standard, requiring proof of fraud or like conduct, ${ }^{77}$ a union is given great latitude to judge its own cause and breach its promises. Though the employer would in theory be able to bring an ordinary breach of contract action in which employee rights could be vindicated without reference to the fair representation standard, the employer is scarcely charged with or committed to representation of worker interests.

The Buzzard employees had specific rights conferred upon them by union promises in the strike settlement agreement, and should have been able reasonably to rely upon those specific guarantees. ${ }^{78}$ A union's flagrant breach of its promises to its members, albeit in the name of union solidarity and discipline, is antithetical to its role as "fiduciary"79 and exclusive employee representative. It ought not be subject only to the usual relaxed test for breach of the duty of fair representation, a test which has allowed few aggrieved employees to prevail upon the merits.

\section{The Fair Representation Standard}

Nonetheless, there exist numerous cases in which specific union promises to members do relate to the negotiation or

\footnotetext{
${ }^{75}$ See text accompanying notes 81-91 infra.

${ }^{76}$ See Clark, supra note 54 , noting that the need for union strength may be small consolation to a discharged employee when the union refuses to take up his grievance, and that absent judicial supervision of union action "the supposed beneficiaries of union strength might never see their share of its fruits." Id. 1120-21.

${ }^{77} \mathrm{See}$ note 53 supra.

${ }^{78}$ This is not to suggest that a union should be deprived of an opportunity to show that it had not in fact breached the literal terms of the strike settlement agreement, but merely that union performance of specific collective bargaining contractual promises ought to be measured by traditional contract standards, and not by the special fair representation-bad faith standard which would presumably excuse the great majority of traditional breaches of contract.

${ }^{79}$ See text accompanying note 51 supra.
} 
administration of a collective bargaining agreement, ${ }^{80}$ so that their breach appears to fall within the ambit of the traditional duty of fair representation. In such cases, the limitations of the fair representation remedy as it is applied make it imperative that employees be allowed to pursue independent, traditional contractual remedies.

The Supreme Court has required, for union conduct to constitute a breach of the duty of fair representation, that such conduct be "arbitrary, discriminatory, or in bad faith," 81 or result in intentionally severe discrimination unrelated to legitimate union objectives. ${ }^{82}$ Lower court phrasings of the fair representation standard include "hostile discrimination,"83 "arbitrariness,"84 and "bad faith arbitrariness."

Lower courts have been hesitant to find union conduct in breach of the duty. With the employee required to overcome a strong presumption of union rectitude, ${ }^{86}$ unions have fared well in defending fair representation suits. Less egregious forms of discrimination and unfairness than raw malice or racial discrimination have been difficult to establish, ${ }^{87}$ with the result that considerable discretion is vested in the union. Commentators have long pointed out that employees with legitimate breach of contract claims against an employer, and legitimate fair representation causes of action against their union, have been unable to obtain relief against either due to the courts' reluctance to equate a union's refusal to process a meritorious grievance with bad faith. ${ }^{88}$

Persuasive union defenses to an employee's suit in the Buzzard context are easy to fabricate and nearly impossible to attack. The union may, for example, simply argue that it did not interpret the strike settlement agreement ${ }^{89}$ as precluding fair disciplinary proceedings against offenders, contending that if its

${ }^{80}$ See, e.g., Humphrey v. Moore, 375 U.S. 335 (1964).

${ }^{81}$ Vaca v. Sipes, 386 U.S. 171, 190 (1967).

${ }^{82}$ Amalgamated Ass'n of St. Employees v. Lockridge, 403 U.S. 274, 301 (1971).

${ }^{83}$ Gainey v. Brotherhood of Ry. \& S.S. Clerks, 313 F.2d 318, 323 (3d Cir. 1963).

${ }^{84}$ Griffin v. UAW, 469 F.2d 181, 183 (4th Cir. 1972).

${ }^{85}$ Buzzard v. Machinists Local 1040, 480 F.2d 35, 40 (9th Cir. 1973).

${ }^{86}$ Local 12, Rubber Workers v. NLRB, 368 F.2d 12, 23 (5th Cir. 1966), cert. denied, 389 U.S. 837 (1967). Criticizing judicial mishandling of the fair representation doctrine, the Rubber Workers court concluded: "[C]onfronted with jurisdictional, monetary, and procedural obstacles, the individual employee may well find his right to fair representation as enforced by the courts more theoretical than real." Id. at 23.

${ }^{87}$ Levy, The Collective Bargaining Agreement As A Limitation On Union Control Of Employee Grievances, 118 U. PA. L. REv. 1036, 1055 (1970).

${ }^{88}$ Comment, The Duty Of Fair Representation In The Administration Of Grievance Procedures Under Collective Bargaining Agreements, 1968 WASH. U.L.Q. 437, 451-52. See also Clark, supra note 54, at 1178 ("In its current muddled state, the duty of fair representation is not fulfilling Steele's promise. As long as courts nourish the bad-faith standard, the law cannot assure that minority interests will be considered at any point in the collective bargaining process.")

${ }^{89}$ See note 9 supra. 
interpretation was erroneous, it was arrived at in good faith. Alternatively, the union might contend that its decision to discipline offenders, albeit in violation of clear contractual agreements, was reasonably necessary to promote union solidarity. The former defense would require a plaintiff to fathom the murky evidentiary waters of union motivation; the latter would threaten to swallow up all of a union's contractual promises in the name of solidarity. ${ }^{90}$ Unless the employer were to sue to enjoin disciplinary proceedings, employees would effectively be denied relief for union breaches of contract. ${ }^{91}$

This effective denial of employee relief, through the interposition of the fair representation standard in employee-union contract disputes, would clearly threaten a major objective of national labor policy: the protection and promotion of the national economy and of industrial tranquility. ${ }^{92}$ Unions could rest content in the knowledge that their promises to employees could be violated at will. Inevitably, they would become less attuned to the desires of their entire membership, and responsive to the will of a majority. Internal disunity would be promoted. Only by recognition of employee-union suits to enforce collective bargaining promises-subject to ordinary breach of contract standards-can courts safeguard the rights of employees, and realistically hope to effectuate national labor policy and deter disruptive and economically harmful union conduct.

Concern for protection of workers' rights is an important and independent aspect of federal labor policy. Given a union's acknowledged role as "fiduciary," the breach of specific union promises to members is no less intolerable when relating to the negotiation or administration of a collective bargaining agreement than when such promises relate solely to employee-union matters. ${ }^{93}$ The subordination of employee interests which would result in such cases if the fair representation remedy were the exclusive avenue of relief appears quixotic, considering the ready availability of a traditional theory which would afford employees added protection. Nonrecognition of an employee breach of contract remedy because of the existence of the fair representation duty would mean that a duty designed to harmonize employee rights and union organizational objectives

90 The fact that the Buzzard employer would have a valid cause of action against the union for breach of contract would, of course, be of no assistance to an employee in proving the union's conduct sufficiently arbitrary to constitute a breach of the fair representation duty. Mere establishment of such a breach would certainly fall short of the "intentional and severe" discrimination required by the Supreme Court in Amalgamated Ass'n of St. Employees v. Lockridge, 403 U.S. 274, 301 (1971).

${ }^{91}$ See text accompanying notes 75-77 supra.

92 See, e.g., Senate Comm. on Labor \& PUblic Welfare, Federal Labor Relations Acr of 1947, S. ReP. No. 105, 80th Cong., lst Sess. 15-16 (1947).

${ }^{83}$ See text accompanying notes $73-79$ supra. 
would operate perversely, protecting illegitimate union conduct at the expense of the clear contractual rights of employees.

\section{Conclusion}

Section 301 should not be construed to authorize employees to bring fair representation suits, not annexed to breach of contract suits, in federal district courts. The right of an employee to sue his union for breach of contract under that section, however, seems well-supported by the words of the statute, the clear preponderance of the case law and the logic of federal labor policy. The duty of fair representation is at best a fragile instrument of worker protection policy. To expand the duty to include purely intraunion conduct unrelated to employee job interests, or to preclude employees from pursuing traditional contractual remedies, would ironically be to confer upon a union undeserved discretion to ignore contracts made with or for the benefit of its members. This would tend to defeat federal policy, which has been to give maximum protection to worker interests while promoting industrial stability. 